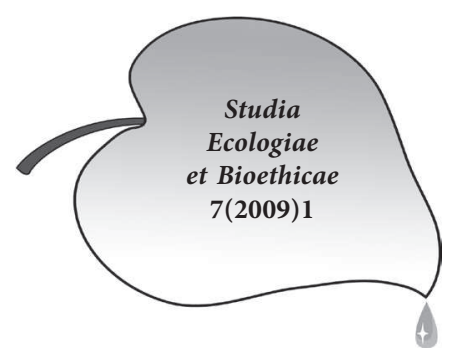

\title{
Wpływ czynników środowiskowych na powstawanie chorób układu krążenia - wybrane problemy
}

Czynniki środowiskowe w różny sposób oddziałując na organizm ludzki, mogą stabilizować, modyfikować, bądź być przyczyną wielu stanów patologicznych, w szczególności układu krążenia (1). Środowiskowe zagrożenie zdrowia to nie tylko negatywny wpływ skażonego środowiska na zdrowie ludzi, obejmujące zagrożenia środowiskowe wynikające $\mathrm{z}$ działalności ludzkiej, ale także wynikające z samego środowiska (2). Dziedzina medycyny zajmująca się wpływem czynników środowiskowych na układ sercowo-naczyniowy, to kardiologia środowiskowa - Environmental Cardiology (3).

Czynniki środowiskowe mogą stać się przyczyną wielu chorób na drodze następujących mechanizmów: stres oksydacyjny; generowanie procesów zapalnych; indukcje układu krzepnięcia krwi; dysfunkcje układu autonomicznego. Stres oksydacyjny odpowiedzialny jest także za odszczepienie czynnika Ik Balfa od jądrowego czynnika transkrypcyjnego NF kB oraz za aktywację czynników NFAT i AP-1. Aktywacja NF-kB skutkuje zawsze nadprodukcją cytokin zapalnych, co sprzyja rozwojowi miażdżycy (4).

Zainteresowanie chorobami układu krążenia wynika w dalszym ciągu Z wysokiej zachorowalności i śmiertelności w krajach uprzemysłowionych (5-9). W Stanach Zjednoczonych rocznie umiera około $1 \mathrm{mln}$ ludzi, z tego na choroby układu krążenia przypada 40\%, w tym główną przyczyną jest choroba niedokrwienna serca (chns). W latach 1960 - 1990 zaobserwowano spadek śmiertelności z powodu chns dzięki licznym programom prewencji chns mającym na celu modyfikację czynników ryzyka chns. W skali świata w latach 1998 - 2002 odnotowano również niewielką poprawę sytuacji zdrowotnej w zakresie chorób układu krążenia. Fakt ten ilustrują zarówno współczynniki umieralności proporcjonalnej, jak i współczynniki umieralności szczegółowej.

W ostatnim okresie (przełom tysiąclecia) odsetek zgonów z powodu chorób układu sercowo-naczyniowego zmalał na świecie z 30,9\% do 29,3\%, zaś współczynnik umieralności szczegółowej zmalał z 283,6 w 1998 roku do 268,8 na 100 tys. w 2002 roku. 
- Dla Europu w 1980 roku wskaźnik ten wynosił on 525,12, w 2002 roku 477,79 na 100 tys. ludności.

- Dla Polski w 1980 roku wielkość tego wskaźnika to 577,54, a w 2002 roku 412,38 na 100 tys. ludności (10-11).

Aktualne trendy to:

$\rightarrow$ wzrost śmiertelności z 28,9 do 36,3\% w latach 1990 - 2020 uwarunkowany wzrostem zachorowań na cukrzycę (12);

$\rightarrow$ wzrost liczby osób otyłych i z nadwagą $(13,14)$;

$\rightarrow$ wzrost liczby obu tych przyczyn łącznie;

$\rightarrow$ rosnąca z wiekiem wykrywalność nadciśnienia tętniczego (15);

$\rightarrow$ połączenie z czynnikami środowiska (16-17).

W grupie przyczyn chorób sercowo - naczyniowych wyróżnia się główne czynniki ryzyka i środowiskowe czynniki ryzyka $(17,18,19)$.

- Do głównych zalicza się: wiek i pleć, nadciśnienie tętnicze, zaburzenia gospodarki lipidowej, nadwagę i otyłość (zaburzenia w odżywianiu), dodatni wywiad rodzinny w kierunku choroby niedokrwiennej serca, niską aktywność fizyczną i palenie tytoniu.

- Środowiskowe czynniki ryzyka są następujące (20-27):

a) Czynniki fizyczne: zanieczyszczenia powietrza, gleby i wody; hałas; pole elektromagnetyczne; temperatura; energia elektryczna; czynniki klimatyczne i meteorologiczne.

b) Czynniki chemiczne: zanieczyszczenia powietrza substancjami drobnocząsteczkowymi (pyły, aerozole); związki organiczne i nieorganiczne; leki; substancje odurzające; zatrucie grzybami; picie alkoholu; bierne palenie tytoniu.

c) Czynniki psychologiczne(28): depresja; wrogość; stres; niskie wsparcie społeczne.

Niekorzystne oddziaływanie czynników środowiskowych na układ sercowonaczyniowy może manifestować się występowaniem objawów choroby niedokrwiennej serca (miażdżycy naczyń wieńcowych), kardiomyopatii roztrzeniowej, zaburzeniami rytmu, zaburzeniami przewodnictwa, nadciśnieniem tętniczym.

Zanieczyszczenia powietrza, gleby i wody, a także żywności mogą być spowodowane różnymi związkami zarówno nieorganicznymi, jak i organicznymi. Najczęściej są to zanieczyszczenia przemysłowe spowodowane przez różne gałęzie przemysłu związkami arsenu, kadmu, kobaltu, parami formaldehydu, amoniaku, azbestu, niestabilnymi związkami niklu, chromu, ekspozycją na benzen, rtęć i innymi, chloro i fluorowodorowęglany oraz innymi. Zanieczyszczenia powietrza substancjami powodującymi choroby, to zanieczyszczenia przemysłowe i zanieczyszczenia miast. Mogą one pochodzić z różnych źródeł (np. są emitowane przez różne gałęzie przemysłu, wyburzania, pożary lasów, przenoszone piaski przez wiatry, pyłki pochodzenia roślinnego, erupcje wulkaniczne). 
Związek umieralności z powodu chorób układu sercowo-naczyniowego i zanieczyszczenia powietrza atmosferycznego jest znany od dawna i potwierdzony obserwacjami epidemiologicznymi. Według Agencji Ochrony Środowiska Stanów Zjednoczonych, zanieczyszczenia te spowodowane są sześcioma podstawowymi składnikami (19): 1 - ozonem; 2 - dwutlenkiem węgla; 3 - dwutlenkiem siarki; 4 - tlenkiem węgla (hemoglobina ma 200 -krotnie większe powinowactwo do tlenku węgla niż tlenu); 5 - związkami ołowiu; 6 - zanieczyszczeniami drobnocząsteczkowymi (pyły, aerozole).

Obecnie uważa się, że niekorzystne skutki oddziaływania ozonu na organizm żywy zachodzą poprzez tworzenie wolnych rodników i wyzwalanie mediatorów zapalenia (endoteliny 1, białka zapalnego makrofagów 1 alfa, działanie silnie reaktywne na utlenianie wielonienasyconych kwasów tłuszczowych).

Dla celów badawczych cząsteczki pyłu zawieszonego $\mathrm{w}$ atmosferze podzielono na trzy frakcje $(2-5,16,17,20,21,26,27)$ :

1) frakcja ultracząsteczek, poniżej 0,1 mikrona (UEP),

2) frakcja akumulacyjna (od 0,1 do 2,5 mikrona). Na cząsteczki te przypada największa masa pyłu zawieszonego. Osadzają się wolno i ich okres półtrwania wynosi 5 - 10 dni, stąd też mają zdolność tworzenia widocznego zamglenia.

3) cząsteczki duże powyżej 1 mikrona.

Cząsteczki pyłów stanowiących największe zagrożenie, niezależnie od ich budowy i pochodzenia mają mniej niż 10 mikronów. Większe cząsteczki są wyłapywane w drogach oddechowych i wymiatane przez system rzęsek, mniejsze natomiast docierają do końcowych odcinków dróg oddechowych i pęcherzyków, gdzie są fagocytowane przez makrofagi i neutrofile. Komórki te następnie uwalniają mediatory zapalenia.

Pozostałe chemiczne składniki zanieczyszczenia powietrza poza drogami oddechowymi mogą oddziaływa na układ sercowo-naczyniowy poprzez zmianę rytmu serca, wywoływanie niemiarowości, wpływ na przewodnictwo bodźców elektrycznych, osłabienie kurczliwości mięśnia sercowego, przyspieszenie rozwoju procesu miażdżycowego, szczególnie w naczyniach wieńcowych.

Badania epidemiologiczne, kliniczne i eksperymentalne udowodniły istnienie dodatniej korelacji między składem otaczającego powietrza, a częstością występowania chorób sercowo-naczyniowych i dróg oddechowych (21).

Zanieczyszczenia powietrza mogą wywoływać choroby układu sercowo-naczyniowego poprzez: stres oksydacyjny, tworzenie wolnych rodników, procesy zapalne, aktywację układu krzepnięcia krwi, dysfunkcję układu autonomicznego.

Zdaniem Brooka i wsp. (5) mechanizm prowadzący do rozwoju chorób układu krążenia w wyniku ekspozycji na pyłowe zanieczyszczenia powietrza może przedstawiać się następująco:

- Frakcja akumulacyjna mikrocząsteczek (zanieczyszczenia przemysłowe, spaliny, zanieczyszczenia miejskie) w wyniku inhalacji do płuc (gromadzone w pę- 
cherzykach płucnych są przyczyną miejscowej reakcji zapalnej) wywołuje ogólnoustrojową reakcję zapalną w wyniku, której dochodzi do:

- przyspieszonego rozwoju i destabilizacji blaszki miażdżycowej,

- zmian właściwości reologicznych krwi (właściwości prozakrzepowe, zwiększona lepkość),

- zaburzenia kurczliwości naczyń (skłonność do nadciśnienia tętniczego), co wydaje się być wynikiem wzmożonej ekspresji endoteliny,

- zaburzenia równowagi układu autonomicznego,

- zaburzenia rytmu serca do nagłego zgonu włącznie.

Zanieczyszczenia powietrza drobnymi cząsteczkami przyczyniają się do wzrostu względnego ryzyka chorób sercowo naczyniowych (nadciśnienie tętnicze, zawał mięśnia sercowego) i to niekorzystne oddziaływanie na układ krążenia może by podobne do działania innych czynników ryzyka choroby niedokrwiennej serca. Może powodować wzrost stężenia cholesterolu w surowicy krwi i przyczyniać się do wzrostu ciśnienia tętniczego (4).

Potwierdzają to również badania przeprowadzone przez innych autorów (20, 21, 26), w których wykazano, że wzrost całkowitej śmiertelności z przyczyn sercowo-naczyniowych był powiązany z tlenkiem węgla, dwutlenkiem azotu, dwutlenkiem siarki, aerozolami zawierającymi atomy siarki, a także zależał od wielkości cząsteczek zanieczyszczeń.

Pewną formą zanieczyszczenia powietrza różnej wielkości cząsteczkami jest smog.

Następstwa wpływu smogu na układ sercowo-naczyniowy to wzrost lepkości krwi, wzrost stężenia białka C reaktywnego oraz zaburzenia rytmu serca (u części badanych). Potwierdziły to badania przeprowadzone w Londynie w 1952 roku, a także inne. W oparciu o 5 dniowe zjawisko smogu w Zagłębiu Ruhry obserwowano wzrost śmiertelności z przyczyn sercowo-płucnych z 8 do $12 \%$ wśród chorych hospitalizowanych i z 12 do $28 \%$ wśród pacjentów ambulatoryjnych $(28,29)$.

Wzrost liczby hospitalizacji z przyczyn sercowo-naczyniowych w przypadku zanieczyszczeń powietrza drobnymi cząsteczkami może by również powiązany $\mathrm{z}$ temperaturą otoczenia.

Koken i wsp. (31) obserwowali maksymalną temperaturę, a także przebadali otaczające powietrze na obecność zanieczyszczeń o wielkości cząsteczek poniżej 10 mikronów i obecności gazów ozonu, dwutlenku azotu, dwutlenku siarki i tlenku węgla w Denver i Kolorado w okresie lipca i sierpnia w latach 1993-1997. W oparciu o uzyskane wyniki badań stwierdzili, że wzrost stężenia ozonu w otaczającym powietrzu powodował zwiększenie liczby hospitalizacji z przyczyn sercowo-naczyniowych (miażdżyca naczyń wieńcowych, zawał serca, przewlekłe serce płucne), dwutlenek siarki powodował wzrost hospitalizacji z powodu zaburzeń rytmu, natomiast tlenek węgla miał znaczący wpływ na rozwój niewydolności krążenia, 
Wysokość temperatury była również ważnym czynnikiem wzrostu liczby hospitalizacji z powodu świeżego zawału serca i niewydolności krążenia. Jednocześnie zmniejszyła się liczba wizyt ambulatoryjnych z powodu chorób sercowo-naczyniowych.

Obecnie największe zainteresowanie wzbudza:

Zanieczyszczenie pyłowe (znaczenie tymczasowej i przewlekłej ekspozycji na pył zawieszony, toksyczność pyłu zawieszonego, określenie, jakie grupy w populacji są najbardziej wrażliwe na pyły zawieszone, określenie, do jakich chorób, czy uwarunkowań fizjologicznych dochodzi po ekspozycji na pył zawieszony).

Pole elektromagnetyczne (wytwarzane przez różne urządzenia elektryczne, w tym również przez telefony komórkowe zwiększa ryzyko zachorowania na choroby układu sercowo-naczyniowego - 32).

Hałas (o częstotliwościach wyższych niż $80 \mathrm{~dB}$ wywołuje efekty niezwiązane z narządem słuchu. Zaliczany jest do czynników prominentnych środowiska. Wywoływany jest głównie poprzez transport, przemysł, dyskoteki, sąsiadów (33). Następstwa hałasu związane z układem krążenia to: skłonność do tachykardii, podwyższone ciśnienie krwi, zwiększone wydalanie katecholamin, następstwa psychologiczne). Udowodniono istnienie związku pomiędzy bliskością źródła hałasu, a wzrostem zachorowań na świeży zawał serca (34). Franssen i wsp. (35) zwracają szczególną uwagę na stan zdrowia osób zamieszkałych w pobliżu dużego lotniska. Badania przeprowadzono na 11.812 mieszkańcach Amsterdamu zamieszkałych w promieniu $25 \mathrm{~km}$ od lotniska Schiphol wykazały istnienie związku między natężeniem hałasu a stanem zdrowia populacji ogólnej. U osób o znacznym natężeniu hałasu występowały: objawy ogólne, objawy ze strony układu krążenia (zaburzenia rytmu, nadciśnienie), zawał serca i niewydolność krążenia. Przy czym w tej grupie obserwowano zmniejszenie częstotliwości wizyt ambulatoryjnych.

Zanieczyszczenia wody pochodzą z różnych źródeł, najczęściej są to zanieczyszczenia spowodowane przez różne dziedziny przemysłu, zanieczyszczenia środkami ochrony roślin, obecność metali ciężkich. Sposób przedostania się zanieczyszczen do wody odbywa się pośrednio i bezpośrednio. Zanieczyszczenia wody na ogół nie utrzymują się długo, zwłaszcza, jeżeli dotyczą metali, które w wyniku procesów utleniania podlegają wytrącaniu.

Twardość wody uzależniona jest od obecności takich pierwiastków, jak wapń i magnez. Obydwa pierwiastki mają znaczenie kardioprotekcyjne, przy czym to działanie jest zależne od stosunku magnezu do wapnia. Im ten stosunek jest większy od jedności, tym jest ono większe. Zdaniem Sauvanta i wsp. (36), a także Lacey’a i wsp. (37) picie twardej wody sprzyja rozwojowi chorób sercowo-naczyniowych. Wnioski swoje autorzy oparli o studia obejmujące publikacje w okresie 1960 - 2000 oraz zaproponowali uznanie twardości wody do picia 
jako dużego czynnika ryzyka choroby niedokrwiennej serca. Studia EUROHEIS (Environment and Health Information System) wykazały istnienie statystycznie istotnego związku między śmiertelnością na choroby układu sercowo - naczyniowego, a piciem twardej wody, przy czym związek ten był bardziej widoczny w chorobach naczyniowo-mózgowych niż sercowo-naczyniowych (38).

Metale, a zwłaszcza metale ciężkie wskutek różnorodnej działalności człowieka w różny sposób dostają się do wody, gleby, żywności, a także mogą stanowi składniki cząstek zanieczyszczających powietrze.

$\checkmark$ Arsen występuje w formie nieorganicznej i organicznej. Znalazł szerokie zastosowanie w przemyśle chemicznym, produkcji szkła, farmaceutyków, elektronicznym, a także jest używany do ochrony drzew, w połączeniu z miedzią oraz w zdobnictwie. Stosuje się go także w hodowlach drobiu w leczeniu i zapobieganiu pasożytom, a także stymulacji wzrostu. Stąd też trafia do żywności. Konsumpcja kurcząt jest źródłem arsenu w populacji ogólnej (39). Drugim źródłem dostarczenia arsenu do organizmu jest picie wody $\mathrm{z}$ jego domieszką lub jego związków. Udział arsenu w patogenezie chorób naczyń obwodowych został udowodniony przez Tsenga i wsp. (40). Badania przeprowadzono na Tajwanie u osób, które piły wodę z podwyższoną zawartością arsenu oraz na terenie północnego Chile po masowym zatruciu związkami arsenu (41). Natomiast udział Arsenu w patologii naczyń wieńcowych w populacji ogólnej jest nie jasny. Zierold i wsp. (42) obserwowali 1185 osobową grupę osób pijących wodę z domieszką arsenu z zawartością od 2-10ppb i stwierdzili częstsze występowanie depresji, nadciśnienia tętniczego, problemów sercowo-naczyniowych prowadzących do częstszych interwencji kardiochirurgicznych (bypassy).

$\checkmark$ Aluminium, metal, który posiada liczne zastosowaniach. Do organizmu przedostaje się poprzez dietę i leki. Wykazuje powinowactwo do układu nerwowego i może spowodować uszkodzenie mięśnia sercowego (43).

$\checkmark$ Ołów jest pierwiastkiem szeroko dostępnym w przyrodzie. Stosowany w różnych gałęziach przemysłu, występuje w różnych produktach przemysłowych, a także stanowi dodatek do paliw. Znajduje się w powietrzu, wodzie, glebie, a stąd trafia do różnych organizmów roślinnych i zwierzęcych. W skali indywidualnej palenie tytoniu jest także źródłem ołowiu. Ze strony układu sercowo-naczyniowego jest przyczyną nadciśnienia tętniczego oraz powoduje wzrost ryzyka chorób sercowo-naczyniowych na tle miażdżycy (46).

$\checkmark$ Rtęć występuje w trzech formach. Jako rtęć metaliczna, organiczna i nieorganiczna. Może znaleźć się w żywności, w mięsie ryb, a także jako składnik amalgamatu służącego do wypełniania ubytku w zębach. Obecność rtęci obniża kardioprotekcyjne działanie nienasyconych kwasów tłuszczowych na układ sercowo - naczyniowy. Udowodniły to badania Guatlara i wsp. (47) u 664 Europejczyków z zawałem mięśnia sercowego, u których stwierdzono 
podwyższony poziom rtęci w paznokciach. Prawdopodobnie niekorzystny mechanizm działania rtęci odbywa się poprzez peroksydację lipidów, uszkodzenie błony komórkowej, uszkodzenie autonomicznego układu nerwowego. Inne badania prowadzone przez Yoshizawę i wsp. (48) nie potwierdziły związku między stężeniem rtęci w paznokciach a zawałem mięśnia serca.

$\checkmark$ Kobalt - w 1960 roku obserwowano w Quebeku rozwój kardiomyopatii u pijących piwo, gdzie stosowano kobalt jako czynnik stabilizujący dojrzewanie piwa. Udział kobaltu w powstawaniu chorób serca w ogólnej populacji jest jednak mało prawdopodobny (49).

$\checkmark$ Kadm należy do najgroźniejszych w skutkach toksykologicznych pierwiastków środowiskowych. Wykorzystuje się go do produkcji stopów, lutów, barwników, akumulatorów, a także tworzyw sztucznych. Innym źródłem kadmu jest tytoń. Do organizmu człowieka trafia wraz z pokarmami pochodzenia węglowodanowego i białkowego. Długotrwałe narażenie na kadm wywołuje miażdżycę naczyń obwodowych i nadciśnienie tętnicze (50).

$\checkmark$ Selen (półmetal) ma związek $\mathrm{z}$ wystąpieniem chorób układu sercowo-naczyniowego. Liczne badania wykazały, że zubożenie organizmu w zasoby selenowe poniżej pewnej wartości progowej, zwiększa ryzyko incydentów sercowonaczyniowych. Nie wykazano jednak, aby suplementacja selenem skutecznie zapobiegała rozwojowi miażdżycy. Uważa się jednak, że przewlekły niedobór selenu sprzyja rozwojowi kardiomyopatii roztrzeniowej, co udowodniono to w przypadku choroby Keshan (51).

Azotany (V) i azotyny (III) powszechnie występują w środowisku człowieka: w glebie wodzie, żywności, co jest naturalną konsekwencją obiegu azotu, zanieczyszczeń antropogenicznych, a także stosowania w różnych gałęziach przemysłu. Szkodliwość azotanów (V) polega na ich redukcji do azotynów (III), co może powodować niekorzystne skutki dla organizmu manifestujące się methemoglobinemią, niedokrwistością, a także produkcją nitrozamin (44). Azotany pod postacią nitrogliceryny, połączeń z glikolem etylenowym znalazły zastosowanie, jako materiały wybuchowe, a także jako środki, które działają bezpośrednio na mięśnie gładkie naczyń, obniżając ich napięcie i powodując rozkurcz. Działanie to odbywa się za pośrednictwem tlenku azotu, który jest najsilniejszym fizjologicznym wazodiletatorem. Zdaniem Hogsteda i wsp. (45) długotrwała ekspozycja na działanie nitratów (pracujący przy produkcji dynamitu) może być przyczyną zwiększonego ryzyka dławicy piersiowej, zawału mięśnia sercowego i nagłej śmierci.

Czynniki chemiczne, w tym rozpuszczalniki są używane dosyć często w miejscu pracy (benzen, chloroform, heptany, toluen, trójchloroetylen, fluororopochodne węglowodorów wywołują zaburzenia rytmu serca (52). Trójchloroetan w wyższych dawkach działa depresyjnie na kurczliwość mięśnia sercowego. Chlorek metylenu stosowany czasami do różnych politur po przedostaniu się do organizmu jest metabolizowany do tlenku węgla. 
Chloro i fluorowodorowęglany uwrażliwiają układ bodźco-przewodzący serca na działanie katecholamin i mogą przyczynić się do powstawania arytmii.

Leki mogą wykazywać szkodliwe, jak i korzystne działanie. Działania te mogą być powiązane albo niepowiązane z głównym działaniem farmakologicznym leku (53). Większość działań niepożądanych można przewidzieć. Często objawy niepożądane ze strony układu krążenia pojawiają się po dłuższym stosowaniu leku, bądź też po dołączeniu kolejnego leku. Objawy ze strony układu sercowo-naczyniowego, jako następstwo niepożądane działania leków możemy podzielić na dwie grupy: 1) objawy sercowo-naczyniowe występujące po lekach kardiologicznych oraz 2) objawy sercowo-naczyniowe występujące po zastosowaniu innych leków np. leków onkologicznych. Doustne środki antykoncepcyjne mogą by przyczyną następujących powikłań ze strony układu sercowo-naczyniowego $(23,54)$ : zakrzepicy żylnej, ryzyka zatoru tętnicy płucnej i nadciśnienia tętniczego. Obecnie stosowane nie zwiększają ryzyka zawału mięśnia sercowego.

Występowanie objawów niepożądanych ze strony układu sercowo-naczyniowego na skutek brania leków uzależnione jest od szeregu czynników $(53,59)$ takich jak: wiek, predyspozycji genetycznych, idiosynchrazji, chorób towarzyszących, interakcji lekowych oraz czasu stosowania leków. Objawy ze strony układu krążenia mogą pojawić się po lekach kardiologicznych oraz po lekach, które włączono do leczenia, nie z powodu chorób układu krążenia. Leki kardiologiczne poza zamierzonym efektem terapeutycznym mogą wywoływać objawy ze strony układu krążenia. Do tej grupy możemy zaliczyć: glikozydy nasercowe (digoksyna), antagoniści receptorów beta adrenergicznych, nitraty (nitrogliceryna), niektóre leki antyarytmiczne (np. hydantoinal) oraz inne, których liczba wzrasta.

Polekowe niepożądane następstwa ze strony układu sercowo-naczyniowego to: zaburzenia rytmu, arytmie, zaburzenia przewodnictwa, bloki przedsionkowo-komorowe I - III stopnia, bloki odnóg pęczka Hisa, wpływ na poszczególne składowe ekg, zaburzenia ukrwienia mięśnia sercowego, kardiomyopatie, niewydolność krążenia, wzrost ciśnienia tętniczego, spadek ciśnienia tętniczego z objawami zapaści ortostatycznej.

Następstwa niepożądane po lekach niezwiązanych z układem krążenia mogą wystąpić po: niektórych lekach stosowanych w leczeniu chorób układu oddechowego np.Teofilina, - niektórych lekach onkologicznych np.Doxorubicyna, niektórych lekach przeciwzapalnych np. refekoksyb i niektórych lekach anorektycznych (Fenfluramina, Deksfenfluramina).

\section{Narkotyki}

$\checkmark$ Kokaina (55) występuje w postaci białego proszku rozpuszczalnego w wodzie, działa sympatykomimetycznie, wywołuje euforię. Objawy niepożądane ze strony układu sercowo-naczyniowego to: indukcja niedokrwienia mięśnia sercowego, zwężenie naczyń wieńcowych, gotowość do tworzenia zakrzepów poprzez ułatwienie agregacji płytek. Może wywoływać niebezpieczne dla ży- 
Wplyw czynników środowiskowych na powstawanie chorób układu krążenia - wybrane problemy

cia arytmie przez wzrost aktywności układu sympatycznego oraz wskutek zaburzenia prawidłowego transportu jonów potasu, wapnia i sodu w miocardium, a także udar mózgu i śródczaszkowe wybroczyny krwawe (55-56).

$\checkmark$ Heroina należy do opiatów wyizolowanych z makowca i jest bardziej niebezpieczna od kokainy. Jest wstrzykiwana dożylnie. U 10\% osób, które zażywały, bądź zażywają heroinę występuje zapalenie wsierdzia z zajęciem zastawki trójdzielnej (57).

$\checkmark$ Marihuana to narkotyk otrzymany z liści cannabis sativa. Wpływa na częstość akcji serca i wzrost ciśnienia tętniczego. U osób ze zwężeniem naczyń miażdżycowych powoduje nasilenie objawów dławicy piersiowej (58).

$\checkmark$ Amfetamina jest strukturalnie podobna do noradrenaliny. Podana doustnie wywołuje objawy ze strony układu krążenia: przyspieszone bicie serca, komorowe zaburzenia rytmu serca, wzrost ciśnienia tętniczego krwi, wyzwala bóle dławicowe. W EKG mogą by stwierdzone cechy niedokrwienia m. sercowego (59).

Czynniki anaboliczno-androgenne stosowane dosyć często w sporcie, jako środki wspomagające, już u osób młodych mogą doprowadzi do dysfunkcji mięśnia sercowego (60 -61).

Alkohol stanowi poważne społeczne zagrożenie. W USA około 100.000 zgonów rocznie ma związek z alkoholem. Bezpośrednie działanie alkoholu na układ sercowo-naczyniowy może powodować: kardiomyopatia roztrzeniowa, obniżenie stężenia HDLi, zwiększenie ryzyka rozwoju chns i nadciśnienie tętnicze. Niewielkie dawki alkoholu mają działanie pozytywne: podnoszą stężenie HDLi, hamują agregację płytek, zmniejszają ryzyko choroby wieńcowej, niektóre składniki napojów alkoholowych wykazują działanie antyoksydacyjne, zwłaszcza czerwone wino, mogą wywierać wpływ na poziom białka C-reaktywnego $(23,62-64)$.

Palenie tytoniu od dawna zostało zaliczone do głównych czynników ryzyka. Uważa się, że w USA palenie tytoniu jest powiązane z 500 tysiącami zgonów w ciągu roku, którym można by zapobiec. Palenie tytoniu ze strony układu krążenia zwiększa ryzyko nagłego zgonu, zawału mięśnia sercowego, dławicy piersiowej, chorób naczyń obwodowych, tętniaka aorty brzusznej i udaru mózgu. Obecnie dużo uwagi poświęca się biernemu paleniu tytoniu. Od dawna znany jest fakt gwałtownego zmniejszenia częstości nawrotów ostrych incydentów sercowo-naczyniowych u osób, które zerwały z nałogiem palenia tytoniu. Liczba szkodliwych związków chemicznych powstałych w następstwie palenia tytoniu przekroczyła kilka tysięcy. W tej masie znajduje się około 60 związków działających rakotwórczo (65-69). Mechanizm niekorzystnego wpływu palenia tytoniu na powstawanie zmian miażdżycowych w naczyniach wieńcowych uzależniony jest od wielu czynników: zwiększonej oksydacji LDL-C, - obniżenia stężenia HDL-C, uszkodzenia zależnego śródbłonka czynnika rozszerzającego naczynia, 
wzrostu stężenia markerów procesu zapalnego (CRP), wzrostu agregacji płytek, wzrostu właściwości zlepnych monocytów w stosunku do komórek śródbłonka

Otyłość definiowana jako wskaźnik (BMI) masy ciała w kg do kwadratu wysokości ciała w m. BMI powyżej 30 powoduje wzrost śmiertelności ogólnej, wzrost liczby zgonów z przyczyn sercowo-naczyniowych, zaburzenia metaboliczne manifestujące się podwyższonym stężeniem LDL-i, cholesterolu całkowitego i obniżonym stężeniem HDL-i, nadciśnieniem tętniczym, upośledzoną tolerancją glukozy, promocją niskiej aktywności fizycznej. Szczególne znaczenie przypisuje się otyłości wisceralnej (WHR) definiowanej jako wskaźnik obwodu talii do obwodu bioder. Na uwagę zasługuje WHR powyżej 0,9 u mężczyzn i powyżej 0,8 u kobiet $(13,14,18,19)$.

Czynniki psychosocjalne odgrywają_szczególną rolę w prewencji pierwotnej i wtórnej choroby niedokrwiennej serca (28). Od dawna znany jest wpływ czynników psychosocjalnych na powstawanie zawału mięśnia sercowego. Udział tych czynników w chorobach układu sercowo-naczyniowego podlegał modyfikacjom na przestrzeni lat. Ostatnio szczególne znaczenie w powstawaniu wymienionych chorób przypisuje się takim składowym jak depresja, wrogość, izolacja społeczna, stres, a także wsparciu społecznemu we wtórnej prewencji.

Przedstawiona próba pokazania wpływu czynników środowiskowych na powstawanie chorób układu krążenia stanowi jedynie wycinek tej problematyki.

Utrzymująca się na wysokim poziomie i wykazująca tendencje wzrostowe umieralność z powodu chorób układu sercowo-naczyniowego wymaga również zwrócenia większej uwagi na czynniki środowiskowe, jakkolwiek pojedynczo wpływ każdego z tych czynników na patogenezę choroby niedokrwiennej serca jest mniejszy niż czynników głównych, to istnieje ich wystarczająca ilość, aby tendencje wzrostowe zapadalności na choroby układu krążenia utrzymać.

\section{Piśmiennictwo}

1. Wolański N.: Ekologia człowieka. Wrażliwość na czynniki środowiska i biologiczne zmiany przystosowawcze. Wyd. Naukowe PWN, Warszawa 2006.

2. Siemiński M.: Środowiskowe zagrożenia zdrowia. Wyd. Naukowe PWN, Warszawa 2001.

3. Bhatnagar A..: Environmental cardiology: Studying Mechanistic Links Between Pollution Heart Disease. Circulation Research, 99:692-705; 2006.

4. Kennedy T., Ghio A.J.: Copper - dependent inflammation and nuclear factor kappa B activation by particulate air pollution. Am J Respir Crit Care Med. 19:366-378, 1998.

5. Brook R.D., Brook J.R., Rajagopalan S.: Zanieczyszczenia powietrza a choroby układu krązenia. Kardiologia po Dyplomie, 3(1):47-55, 2004.

6. Driscoll K.E., Carter J.M., Hassenbein D.G., and Howard B.: Cytokines and particle induced inflammatory cell recruitment. Environ Health Persp. 105:1159-1164, 1997.

7. Libby P., Ridker P.M., Maseri A.: Inflammation and Atherosclerosis. Circulation, 105:1135 $1143,2002$. 
8. Ridker PM, Genest J, Libby P.: Risk Factors for Atherosclerotic Disease. W ks:" Heart Disease", Braunwald E., Zipes DP, Libby P. - red. Wyd. WB Saunders Comp. Ed.6, 1010-40, Philadelfia, 2003.

9. Sumeray MS., Montgomery ME., Humphries SE.: Beyond Coagulation: Fibrinogen as a cause of Cardiovascular Surgical Disease. Cardiovasc Drugs Therapy, 12:261-65, 1998.

10. Maniecka-BryŁa I, BryŁa M, Drygas W.: Sytuacja epidemiologiczna w zakresie chorób układu krążenia na początku XXI wieku. Cz. I. Świat. Zdr. Publ., 116(3):423-426, 2006.

11.Maniecka-BryŁa I., BryŁa M., Drygas W.: Sytuacja epidemiologiczna w zakresie chorób układu krążenia na początku XXI wieku. Cz.II. Europa. Zdr. Publ., 116(3):427-430, 2006.

12. DiLiberti JH., Rodney PHD, Lorentz A.: Long Term Trends in Childhood Diabetes Mortality: 1968 - 1998. Diabetes Care 24:1348 - 1352, 2001.

13. Kopelman P.G.: Obesity as a Medical Problem. Nature, 404:635, 2000.

14. Wiткошsкa M.: Otyłość jako czynnik zagrożenia chorobami sercowo-naczyniowymi. Medycyna po Dyplomie, 4 wydanie spec., 2-4, 2004.

15. HaJjar I, Kotchen TA.: Trends in prevalence, awareness treatment and control of hypertension in the United States 1998-2000. JAMA, 290:199, -2003; 2006.

16. Bhatnagar A.: Cardiovascular pathophysiology of environmental pollutans. Am J. Physiol Heart Circ Physiol., 286:479-485, 2004.

17. RosenLund M.: Environmental Factors in Cardiovascular Disease. Doctoral Thesis, Stockholm 2005.

18. Ridker PM, Genest J, Libby P: Risk factors for Atherosclerotic Disease. W ks.:" Heart Disease", pod red. Brauwald E., Zipes D.P., Libby P. WB Saunders Comp. Ed 6, Philadelphia 1010-1040, 2003.

19. KośmiŃski M.: Wieńcowe czynniki ryzyka. Przewodnik Lek, 3(63):88-93, 2004.

20.Brook RD, Franklin B, Cascio W., Hong Y., Howard G., Lipsett M, Luepker R., Mittleman M, Samet J, Smith JR. SC,Tager I.:Air Pollution and Cardiovascular Disease: A Statement for Helthcare Professionals From the Expert Panel of Population And Prevention Science of the American Heart Association. Circulation 2004;109: 2655-2671.

21.Kunzli N., Tager IB: Air pollution: from lung to heart. Swiss Med Wkly, 135(47-48):697-702, 2005.

22. Magari SR, Schwartz J., Williams PL, Hauser R., Smith TJ, Christiani DC..: The association between personal measurements of environmental exposure to particulates and heart rate variability. Epidemiology, 13(3):305-310, 2002.

23. Maitra A., Kumar V.: Choroby środowiskowe .W: Patologia, Kumar V, Cotran RS i Robbins SL - red, Wyd. Urban \& Partner, 301-350, Wrocław 2005.

24.Hinwood AL., De Klark N., Rodriquez C., Jacoby P., Runnion T., Rye P., Landau L., Murray F., Feldwick M., Spickett J.: The relationship between changes in daily air pollution and hospitalizations in Perth. Australia 1992 - 1998, a case crossover study. Int J Environ Health Res, 16(1):2746, 2006.

25. Hill JS, Hayden MR, Frohlich J, and Pritchard PH.: Genetic and Environmental Factors Affecting the Incidence of Coronary Artery Disease in Heterozygous Familiar Hypercholesterolemia. Arterioscler Tromb Vasc Biol., 11:290-297, 1991.

26. Glantz SA: Air Pollution as a cause of heart disease. J Am Coll Cardiol., 30:943-45, 2002.

27. DoCKERY DW: Epidemiologic evidence of cardiovascular effects of particulate air pollution. Environ Health Perspect., 109 (supll 4):483-486, 2001.

28. Everson - Rose SA, Lewis TT: Psychosocial Factors and Cardiovascular Diseases. Annu Rev Public Health, 26:469-500, 2005.

29. Wichmann HE: What can we learn today from the Central European smog episode of 1985 (and earlier episodes). Int J Hyg Health., 207(6):505-20, 2004. 
30. Wichmann HE: 20 years after the winter smog episode 1985 - the particle problem then and today. Int J Hyg Environ Health, 207(6):489-91, 2004.

31. Koken PJ, Piver WF, Ye F et al.: Temperature, air pollution and hospitalization for cardiovascular diseases among elderly people in Denver. Environ Health Pespect., 111(10):1312-17, 2003.

32. Feuchting M, Ahlbom A, Kheifets L.: EMF and Health. Annu Rev Public Health, 26:165-89, 2005.

33. Van Kempen EE, Kruize H, Boshuizen HC,Ameling CB,Staatsen BA, de Hollander A E.: The association between noise exposure and blood pressure and ischemic heart disease: a meta analysis. Environ Health Perspect., 110(3):307-17, 2002.

34. Rosenlund M.: Environmental Factors in Cardiovascular Disease. Doctoral Thesis, Stockholm 1995.

35. Franssen EA, van Wiechen CM, Nagelkerke NJD, Lebret E.: Aircraft noise around a large international airport and ist impact on general health and medication use. Occup Environ Med., 61(5):405-13, 2004.

36. Sauvant MP, Pepin D.: Drinking water and cardiovascular disease. Food Chem Toxicol., 40(10):1311-25, 2002.

37.LACEY RF, SHAper AG: Changes in water hardness and cardiovascular death rates. Int J Epidemiol., 13(1);18-24, 1984.

38.EUROHEIS: Atmosphere - Air pollution modelling for support to policy on Healty and Environmental Risk in Europa. Study from summer 2005 and of June 2007.www.euroheis. org

39. Lasky T., Sun W., Kadry A., Hoffman M.: Mean Total Arsenic Concentrations in Chicken 1989-2000 and Estimeted Exposures for Consumers of Chicken, Environmental Health Perspectives, 112:18-21, 2004.

40.Tseng C., Chong CK, Chiu HY, Hsueh YM, Chen CJ.: Arsenic exposure and peripheral vascular disease.Chin J Public Health, 18(suppl 6): 1551-62, 1999.

41. Rosenberg H: Systemic arterial disease and chronic arsenicism in infants. Arch Pathol., 97:360$365,1974$.

42.Zierold K, Knobeloch L, Anderson H: Prevalence of chronic diseases in adults exposed to arsenic-contaminated drinking water. Amer J Public Health, 94(11):1936-37, 2004.

43. NAYAK P.: Aluminium impacts and disease. Environ Res., 89(2),101-115, 2002.

44.Szczerbiński R., Karczewski J., FiŁon J.: Azotany (V) w wodzie do picia jako czynnik ryzyka zdrowotnego ludności województwa podlaskiego. Roczn. PZH, 1:39-48, 2006.

45. Hogstedt C, Axelson O: Nitroglicerin - nitroglicol exposure and the mortality in cardiocerebrovascular diseases among dynamite workers. J Occup Med., 19:675-678, 1977.

46. Cheng Y., Schwartz J., Sparrow D., Aro A., Weeis ST, Hu H.: Bone lead and blood lead levels in relation to baseline blood pressure and the prospective development of hypertension: the normative aging study. Am J Epidemiol., 153:164-71, 2001.

47.Seghizi P., D’Adda F., Borlei D., Barbic F., Mosconi G.: Cobalt myocardiopathy. A critical review of literature. Sci Total Environ., 150(1-3):105-109, 1994.

48. Guallar F., Sanz-Gallardo Mi, van,t Veer P., Bode P., Aro A., Gómez-Aracena J., Kark JD, Riemersma RA, Martin-Moreno JM, KoK FJ: Mercury, fish oils and the risk of myocardial infarction. N Engl J Med., 347(22):1747-54, 2002.

49. Yoshizawa K., Rimm EB, Morris JS, Spate Vl, Hsieh CC, Spiegelman D., Stampfer MJ, Willet WC.: Mercury and the risk of coronary heart disease in men. N Engl J Med., 347(22)1755-60, 2002.

50.NAKagaWA H., Nighijo M.: Enviromental cadmium exposure, hypertension and cardiovascular risk. J Cardiovasc Risk, 3(1):11-17, 1996.

51.ZAGRoDZKi P., ŁAszczyK P.: Selen, a choroby układu sercowo naczyniowego - wybrane zagadnienia. Postępy Hig Med Dośw., 60:624-631, 2006.

52. Fine L.: Occupational diseases of the heart. W: Environmental and Occupational Medicine, 2-gie wydanie, W. Rom - red, Boston, Little Brown, 1992. 
53. Rang HP, Dale MM, Ritter JM: Farmakologia kliniczna, 242-270, Wyd. Czelej, 2001.

54. Vandenbroucke IP, Rosing J, Bloemenkamp KWM, Middeldorp S, Helmerhorst FM, Bouma BN, AND RosendaAl FR: Oral contraconceptives and the risk of venous trombosis. N Engl J Med., 344(20):1527- 35, 2001.

55. Kloner RA, Hale S., Alker K. and Rezkalla: The effects of acute and chronic cocaine use on the heart. Circulation, 85:407-419, 1992.

56. Dhar R., Stout CW, Link MS, Homoud MK, Weinstock J., Estes NA: Cardiovascular toxicities of performance-enhancing substances in sport. Mayo Clin Proc., 80:1307-1315, 2005.

57. Sporer KA: Acute heroin overdose. Ann Intern Med, 130:584, 1999.

58. Ashton CH: Pharmacology and effects of cannabis: a brief review. Br J Psychiatry, 178:101-6, 2001.

59. JАсов LS: Farmakologia, Wyd. Med. Urban and Partner, 31-32, Wrocław, 2002.

60. Gauthier J.: Coeur of dopage. Arch Malad Coeur Vaiss, 99(11):1126-9, 2006.

61.D’Andrea A., Caso P., Saterno G., scarafile R., De Corato G., Mita C., Di Salva G., Severino S., Cuomo S., Liccardo B., Esposito N., Calabro R.: Left ventricular early myocardial dysfunction after chronic misuse of anabolic androgenic steroids a Doppler myocardial and strain imaging analysis. Brit J Sports Med., 41:149-155, 2007.

62. Klatsky AL: Alcohol and cardiovascular diseases: a historical overview. Ann N Y Acad Sci., 957:7-15, 2002.

63. Tavani A., Bertuzzi M., Negri E., Sorbara L., La Vecchia C.: Alcohol, smoking, coffee and risk of non-fatal acute myocardial infarction in Italy. Eur J Epidemiol., 17(12):1131-7, 2001.

64.Albert MA, Glynn RJ, Ridker PM: Spożycie alkoholu a stężenie białka C reaktywnego w osoczu. Circulation, 107:443-447, 2003.

65. Joseph AM, Lawrence CA: Palenie tytoniu a choroby układu sercowo-naczyniowego. Kardiologia po Dyplomie 1(1):77-87, 2002.

66. TAYlor AE, Johnson DC, KAZEMi H.: Environmental tabacco smoke and cardiovascular disease. A position paper from the Council and Cardiopulmonary and Critical Care. American Heart Association. Circulation 86(2), 699-702, 1992.

67. Riddoch CH, Dawn E., Page A., Froberg K., Andressen SA,Wedderkopp N., Brage S., Cooper AR, Sardinha LB, Haro M., Klasson- Haggebo L., van Mechelen W., Boreham C., Ekelund U., Andersen LB and the European Youth Heart Study team: The European Youth Heart Study - Cardiovascular Disease Risk Factors in Children: Rationale, Aims, Study Design, and Validation of Methods. J Phys Activ Healthy, 2:115-129, 2005.

68. Smith CJ, Fischer TH, Sears SB: Environmental tobacco smoke cardiovascular disease, and the nonlinear dose-response hypothesis. Toxical Sci., 54(2):462-72, 2000.

69. WiLson PWE: Palenie tytoniu, rzucenie palenia a ryzyko chorób układu krążenia. Medycyna po Dyplomie 16:10(139):32-37, 2007.

70.SChetTler T.: Heart Disease and the Environment. www.sehn.org, 2005. 


\title{
The influence of environmental factors on pathogenesis of circulation system diseases - selected problems
}

\begin{abstract}
SUMMARY
Environmental factors affect human organism in many ways. They can stabilize, modify or be the cause of many diseases, particularly of circulation system. Diseases of circulation system at the end of the last millennium in USA were the cause of $38 \%$ of all deaths. Such high degree of mortality causes necessity of undertaking prophylactic actions in order to reduce the negative influence of risk factors, particularly those environment factors which influence on pathogenesis of some diseases can be modified. Environment might be the factor which causes heart disease by: oxidation stress, inflammatory process, induction of coagulation system, dysfunction of autonomic system. Schetler (70) divided the factors favoring diseases of circulation system into two groups: risk factors (which have admitted participations in pathogenesis of heart and vascular diseases) and environmental factors which significance in pathogenesis of heart diseases still increases. It is commonly acknowledged that environmental factors which favor development of many diseases of circulation system belong to: physical factors polluting the air, water, soil and food, noise, electromagnetic field, ionizing radiation and electric energy. Most of them are industrial pollution - organic and non-organic. They include also six basic air pollution compounds (ozone, $\mathrm{CO} 2, \mathrm{SO} 2, \mathrm{CO}, \mathrm{PbO} 4$, dust); chemical elements $(\mathrm{Pb}$, $\mathrm{Hg}, \mathrm{Cd}, \mathrm{CO}$, As, lack of Se); medicaments; alcohol and drug inducing stupor; smoking and passive smoking. Also malnutrition and low physical activity increase the risk of occurrence of many circulation system diseases. The described situation is magnified by the fact, that present civilization still increases the number of environmental factors negatively influencing heart-vascular system.
\end{abstract}

Key words: Environmental risk factors, cardiovascular disease 